\title{
THE AVERAGE WEIGHT OF FISH CAUGHT BY ANGLERS AT THE CROATIAN SECTION OF THE SAVA RIVER CATCHMENT
}

\author{
Tomislav Treer
}

Department of Fisheries, Apiculture, Wildlife Management and Special Zoology, Faculty of Agriculture, University of Zagreb, Svetošimunska 25, 10000 Zagreb, Croatia

*Corresponding Author: treer@agr.hr

\section{ARTICLE INFO}

Received: 1 February 2021

Accepted: 18 February 2021

Keywords:

Freshwater

Recreational fishermen

Cyprinus carpio

Silurus glanis

Esox lucius

Sander lucioperca

How to Cite

\section{ABSTRACT}

The aim of this research is to compare the average individual weight of the four most important fish species in fisheries (Cyprinus carpio, Silurus glanis, Esox lucius and Sander lucioperca), caught by angling in different parts of the Sava River catchment in Croatia. Significant differences were expressed between the counties along the Sava River catchment, with the smallest specimens $(p<0.05)$ caught in Vukovar-Sirmium county. Artisanal fishery is mostly developed in that part of the Sava River, along with angling in both countries - Croatia and Bosnia and Herzegovina. Furthermore, the inflow of the River Bosna passes through urban and industrial cities of Bosnia and Herzegovina. It can be concluded that implementing recreational fishing surveys with the specific aim of obtaining data on average individual weight is useful for fishery management.

Treer, T. (2021): The average weight of fish caught by anglers at the Croatian section of the Sava River catchment. Croatian Journal of Fisheries, 79, 7174. DOI: $10.2478 /$ cjf-2021-0008. 


\section{INTRODUCTION}

It is well known that the average weight of the fish caught is an important indicator of the state of fish populations. The raise of the fishing effort results in a lower average individual weight (e.g. Zwanenburg, 2000; Pawlowski and Lorance, 2009; Zimmermann et al., 2011, Valles et al., 2015), i.e. in higher number of fish per weight unit. This can be applied to the ichthyocenoses as well. The fact that higher fishing effort primarily reduces bigger species was used to create $A B C$ (abundance biomass comparison) diagrams (Lamshead et al., 1983; Warwick, 1986; Clarke and Warwick, 1994).

The Sava River is the longest Croatian river with the biggest catchment area, being part of the Danube catchment area (Hrvatske vode, 2017). The upper part of the river is entirely located in Croatia where only recreational fisheries by angling is allowed. In the lower part of the river that flows along the border with Bosnia and Herzegovina, angling as well as commercial (i.e. artisanal) fisheries are allowed in both countries. Therefore, the aim of this research is to compare the average weight of the most important fish species caught by angling in different parts of the Sava River catchment in Croatia.

\section{MATERIAL AND METHODS}

The official data was obtained by the competent Fishery Division of the Croatian Ministry of Agriculture (HŠRS, 2005; 2006; 2007; 2008; 2009; 2010; 2011; 2012; 2013; 2014; 2015; 2016; 2017). Data from the annual angling reports is based on the data from individual angling logbooks collected from all freshwater fishing clubs in Croatia. In spite of all potential limitations, these data can be useful in defining the trend in the catch (e.g. Lyach, 2020). Recreational fishermen are only allowed to engage in angling. Besides maximum daily catch, they are also limited by the number of rods and hooks which they can use, as well as by the seasons and locations closed for fishing. The average weight of the following four most important fish species was calculated across the counties in the Sava River catchment for 13 years (from 2005 to 2017): common carp (Cyprinus carpio Linnaeus, 1758), wels catfish (Silurus glanis Linnaeus, 1758), northern pike (Esox Lucius Linnaeus, 1758) and perch-pike (Sander lucioperca (Linnaeus, 1758)). Five of these counties are located at the Sava River (Zagreb, City of Zagreb, Sisak-Moslavina, Slavonski Brod-Posavina and VukovarSirmium), while the other three are located at the Sava catchment area (Krapina-Zagorje, Bjelovar-Bilogora and Požega-Slavonia). All the waters in each county are included, both flowing and stagnant. Analysis of variance (ANOVA) was calculated using IBM SPSS Statistics 19.

\section{RESULTS AND DISCUSSION}

The average individual weight of all four investigated species expressed significant differences between the counties along the Sava River catchment (Table 1). In Vukovar-Sirmium county, the smallest specimens $(p<0.05)$ of pike, wels catfish and pike-perch were caught. The average weight of common carp in this county was the second smallest, but not significantly different from it. In the part of the Sava River in Vukovar-Sirmium county, the artisanal fishery is most developed. The investigation performed by Treer and Kubatov (2017) showed that commercial fishermen, due to their fishing tools, catch fish of higher individual weight than anglers. Furthermore, in this section of the Sava River, from its right bank, commercial and recreational fishermen from Bosnia and Herzegovina also catch fishes. All of this makes fishing pressure much higher than in upstream counties where only Croatian anglers can fish. Mehl (1991) reported that after World War II the average cod weight decreased by $50 \%$ due to the high fishing mortality. Similarly, the average weight of demersal fish species on the Scotian Shelf in Canada decreased with a doubling of fishing effort and was more prevalent for target species than non-target ones (Zwanenburg, 2000). Zimmermann et al. (2011) stated that a simple negative relationship between fishing effort and average individual weight can be assumed.

However, besides the fishing effort, Sukop et al. (1994) showed the influence of pollution on the average weight of fish by the example of the Dyje River in the Czech Republic. After the construction of waterworks on that river, the quality of water was improved and the quantity of natural food increased. Improvement of the environmental conditions for the fishes led to increasing individual weights of fishes. The River Bosna passes through urban and industrial cities before the inflow in the lower section of the Sava River. That, together with higher fishing effort, possibly negatively affects the average fish size. Smallwood and Ryan (2020) stated that implementing recreational fishing surveys with a specific aim of obtaining data on average weight for this sector is rare, so it should be used more extensively, along with other issues connected with recreational fisheries (Matulić et al., 2010). 
Table 1. Average weight (g) with $95 \%$ confidence limits $(\mathrm{CL})$ according to species and counties (K-Z= Krapina-Zagorje, Zag= Zagreb, $\mathrm{GZ}=$ City of Zagreb, S-M= Sisak-Moslavina, B-B= Bjelovar-Bilogora, P-S = Požega-Slavonia, B-P= Slavonski Brod-Posavina, V-S= Vukovar-Sirmium). Averages for the same species with different superscript letters are significantly different $(p<0.05)$. The biggest average weights are presented by superscript a.

\begin{tabular}{|c|c|c|c|c|}
\hline Species & County & Average & 95\% CL lower & 95\% CL upper \\
\hline \multirow{8}{*}{$\begin{array}{l}\text { Common carp } \\
\text { Cyprinus carpio }\end{array}$} & $K-Z$ & $2192^{\mathrm{b}}$ & 2037 & 2347 \\
\hline & Zag & $2297^{b}$ & 2189 & 2404 \\
\hline & GZ & $2611^{\mathrm{a}}$ & 2372 & 2850 \\
\hline & S-M & $2561^{\mathrm{ab}}$ & 2381 & 2741 \\
\hline & B-B & $1797^{d}$ & 1701 & 1893 \\
\hline & P-S & $2146^{b c}$ & 2009 & 2283 \\
\hline & B-P & $2343^{a b}$ & 2095 & 2592 \\
\hline & V-S & $1890^{\mathrm{cd}}$ & 1708 & 2072 \\
\hline \multirow{8}{*}{$\begin{array}{l}\text { Wels catfish } \\
\text { Silurus glanis }\end{array}$} & $K-Z$ & $4732^{b}$ & 4312 & 5153 \\
\hline & Zag & $5986^{a}$ & 5246 & 6726 \\
\hline & $\mathrm{GZ}$ & $6700^{a}$ & 4669 & 8730 \\
\hline & S-M & $3788^{c}$ & 3337 & 4240 \\
\hline & B-B & $4774^{a, b}$ & 4045 & 5504 \\
\hline & P-S & $4997^{a, b}$ & 3886 & 6108 \\
\hline & B-P & $3697^{c}$ & 3468 & 3925 \\
\hline & V-S & $2624^{d}$ & 2488 & 2760 \\
\hline \multirow{8}{*}{$\begin{array}{l}\text { Pike-perch } \\
\text { Sander lucioperca }\end{array}$} & $K-Z$ & $1735^{b c}$ & 1529 & 1941 \\
\hline & Zag & $1943^{a b}$ & 1796 & 2089 \\
\hline & $\mathrm{GZ}$ & $1905^{b}$ & 1657 & 2152 \\
\hline & S-M & $2314^{a}$ & 1968 & 2660 \\
\hline & $B-B$ & $1575^{c}$ & 1453 & 1697 \\
\hline & P-S & $2037^{a b}$ & 1834 & 2239 \\
\hline & $B-P$ & $2024^{\mathrm{ab}}$ & 1846 & 2202 \\
\hline & V-S & $1540^{c}$ & 1340 & 1741 \\
\hline \multirow{8}{*}{$\begin{array}{l}\text { Northern pike } \\
\text { Esox lucius }\end{array}$} & $K-Z$ & $2336^{a}$ & 2169 & 2503 \\
\hline & Zag & $2127^{a}$ & 2033 & 2221 \\
\hline & $\mathrm{GZ}$ & $2530^{\mathrm{a}}$ & 2028 & 3032 \\
\hline & S-M & $2128^{a}$ & 1837 & 2419 \\
\hline & B-B & $2196^{\mathrm{a}}$ & 2013 & 2379 \\
\hline & P-S & $2402^{\mathrm{a}}$ & 2134 & 2670 \\
\hline & B-P & $1830^{b}$ & 1711 & 1948 \\
\hline & V-S & $1339^{c}$ & 1249 & 1429 \\
\hline
\end{tabular}




\section{PROSJEČNA MASA RIBIČKOG ULOVA U HR- VATSKOM DIJELU PORJEČJA SAVE}

\section{SAŽETAK}

Cilj ovoga rada je usporediti prosječnu individualnu masu četiri najvažnije vrste riba u ribarstvu (Cyprinus carpio, Silurus glanis, Esox lucius i Sander lucioperca) uhvaćenih udičarenjem u različitim dijelovima porječja rijeke Save. Značajne razlike su utvrđene među županijama, sa značajno najmanjim primjercima $(p<0,05)$ ulovljenim $u$ Vukovarsko-srijemskoj županiji. Na tom je dijelu rijeke najrazvijeniji komercijalni ribolov, zajedno s rekreacijskim iz obje države - Hrvatske i Bosne i Hercegovine. Uz to, tu se nalazi ušće rijeke Bosne koja prolazi kroz urbana i industrijska područja Bosne i Hercegovine. Moguće je zaključiti da je uključivanje podataka o prosječnim individualnim masama riba ulovljenih u rekreacijskom ribolovu korisno za ribarsko gospodarenje.

Ključne riječi: slatke vode, rekreativni ribolovci, Cyprinus carpio, Silurus glanis, Esox lucius, Sander lucioperca

\section{REFERENCES}

Clarke K. R., Warwick R., M. (1994): Change in marine communities: an approach to statistical analysis and interpretation. Natural Environment Research Council UK, $114 \mathrm{pp}$

Hrvatske vode (2017): Sava - rijeka s najduljim vodotokom u Hrvatskoj. https://www.voda.hr/hr/novosti/savarijeka-s-najduljim-vodotokom-u-hrvatskoj (accessed on February 17th 2021)

HŠRS (2005): Popis godišnjeg ulova u športskom ribolovu 2005.

HŠRS (2006): Popis godišnjeg ulova u športskom ribolovu 2006.

HŠRS (2007): Popis godišnjeg ulova u športskom ribolovu 2007.

HŠRS (2008): Popis godišnjeg ulova u športskom ribolovu 2008.

HŠRS (2009): Popis godišnjeg ulova u športskom ribolovu 2009.

HŠRS (2010): Popis godišnjeg ulova u športskom ribolovu 2010.

HŠRS (2011): Popis godišnjeg ulova u športskom ribolovu 2011.

HŠRS (2012): Popis godišnjeg ulova u športskom ribolovu 2012.

HŠRS (2013): Popis godišnjeg ulova u športskom ribolovu 2013.
HŠRS (2014): Popis godišnjeg ulova u športskom ribolovu 2014.

HŠRS (2015): Popis godišnjeg ulova u športskom ribolovu 2015.

HŠRS (2016): Popis godišnjeg ulova u športskom ribolovu 2016.

HŠRS (2017): Popis godišnjeg ulova u športskom ribolovu 2017.

Lamshead P. J., Platt H., M., Shaw K. M. (1983): The detection of difference among assamblages of marine benthic species based on an assessment of dominance and diversity. J. Nat. Hist., 17: 859-874.

Lyach R. (2020): The effect of a large-scale angling restriction in minimum angling size on harvest rates, recapture rates, and average body weight of harvested common carps Cyprinus carpio. Fisheries Research, 223.

Matulić, D., Šprem, N., Piria, M., Tomljanović, T., Treer, T., Safner, R., Aničić, I. (2010): Analysis of Recreational Fisheries in the Croatian Areas of the Sava and Danube Rivers. Agriculturae Conspectus Scientificus, 75, 183190.

Mehl S. (1991): The Northeast Arctic Cod Stocks Place In The Barents Sea Ecosystem In The 1980s - An Overview. Polar Research, 2: 525-534.

Pawlowski L., Lorance P. (2009): Effect of discards on roundnose grenadier stock assessment in the Northeast Atlantic. Aquatic Living Resources, 22: 573-582.

Smallwood C. B., Ryan K. L. (2020): Benefits of a restricted spatial and temporal survey design for determining average weight of recreational catches. Fisheries Research, 232.

Sukop I., Spurny P., Turansky R. (1994): Food Biology of the Fishes in the Dyje River Under Waterworks at NoveMlyny. Zivocisna Vyroba, 39: 77-83.

Treer T., Kubatov I. (2017): The co-existence of recreational and artisanal fisheries in the central parts of the Danube and Sava rivers. Croatian Journal of Fisheries, 75: 116-127.

Valles H., Gill D., Oxenford, H. A. (2015): Parrotfish size as a useful indicator of fishing effects in a small Caribbean island. Coral Reefs, 34: 789-801.

Warwick R. M. (1986): A new method for detecting polluting effects on marine microbenthic communities. Mar. Biol., 92: 557-562.

Zimmermann F., Steinshamn S. I., Heino, M. (2011): Optimal harvest feedback rule accounting for the fishing-up effect and size-dependent pricing. Natural Resource Modeling, 24: 365-382.

Zwanenburg K. C. T. (2000): The effects of fishing on demersal fish communities of the Scotian Shelf. ICES Journal of Marine Science, 57: 503-509. 